\title{
MUDANÇAS, BRINQUEDOS E BRINCADEIRAS \\ NO ESPAÇO DA EDUCAÇÃO INFANTIL
}

Samara Soares Machado

Elaisa Maria da Silva

\section{CONHECENDO O GRUPO 3A}

O grupo 3A é acompanhado pela professora Cristiane e composto de 8 (oito) crianças com idade média de 2 (dois) anos. Durante a semana de observação participante (realizada no primeiro semestre de 2008) encontramos duas bolsistas de psicologia (Bianca e Clara) que atuavam conjuntamente com a professora desempenhando, entre outros, o papel de auxiliares de sala. Quando retornamos à instituição na oitava fase do curso, a professora Cristiane já estava com outras duas bolsistas: Milena e Ana. A última bolsista citada tinha como foco principal das suas intervenções no grupo, o cuidado e a educação de uma criança que exigia um atendimento diferenciado, considerando que a mesma tinha necessidades especiais. No entanto, ressaltamos que estas intervenções ña ocorriam de modo isolado ao grupo como um todo. Contrário a isso, a bolsista, assim como os demais adultos aqui citados, atuavam conjuntamente, buscando sempre a participação e inserção efetiva de todas as crianças em todos os momentos do cotidiano destas na instituição. As crianças que compunham o grupo $3 \mathrm{~A}$ :

\begin{tabular}{|c|c|}
\hline MENINAS & DATA DE NASCIMENTO \\
\hline Emanuella & $21 / 06 / 2006$ \\
\hline Lorena & $20 / 07 / 2006$ \\
\hline Mirela & $24 / 07 / 2006$ \\
\hline Sofia & $16 / 04 / 2006$ \\
\hline Stella & $05 / 07 / 2006$ \\
\hline MENINOS & DATA DE NASCIMENTO \\
\hline João Victor & $06 / 04 / 2006$ \\
\hline Joaquim & $03 / 07 / 2006$ \\
\hline Rafael & $22 / 07 / 2006$ \\
\hline
\end{tabular}




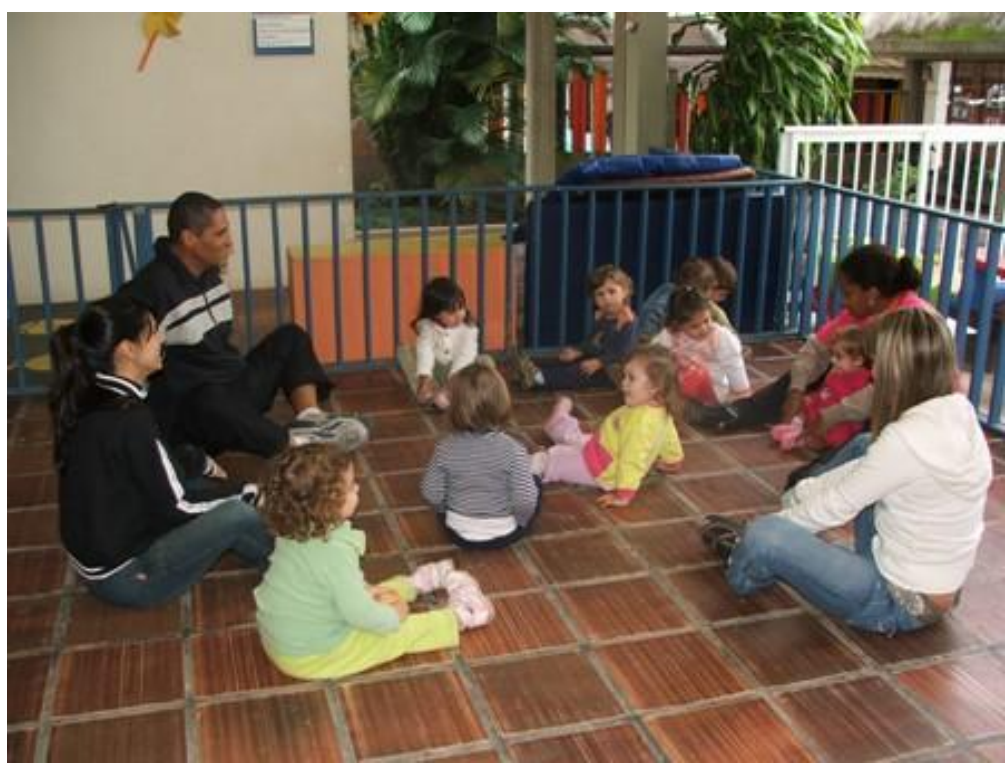

Durante a semana de observação, a estagiária Samara com o grupo 3A em atividade com professor

Gilberto (08/05/08). Nesta foto, as crianças do grupo 3A estavam em uma atividade com o professor de Educação-física Gilberto, onde ele e as crianças imitavam os animais: fazia gestos e sons de leão, cachorro, cobra, gato, sapo e borboleta.

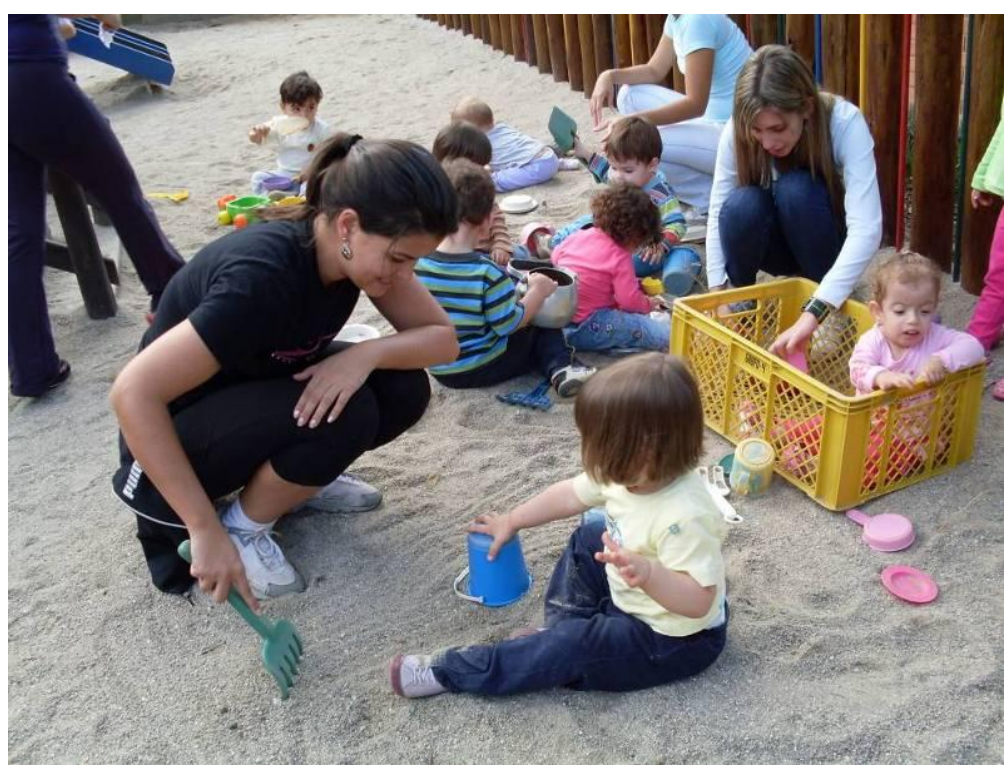

Aluna-estagiária Elaisa (blusa preta) com Stella do grupo 3A no parquinho durante a semana de observação. (18/08/08)

As necessidades especiais de uma das crianças do grupo é consequiência da Mielomeningocele, ou seja, um distúrbio do tubo neural (DTN) que gera a má formação da 
medula espinhal ou coluna vertebral, freqüentemente a nível torácico e lombar, por não fechamento do tubo neural inferior. Os cuidados singulares para com esta criança, passa desde os aspectos voltados a alimentação - pois, caso não queira comer via oral, deve ser alimentada através de uma sonda - à ações socioeducativas diferenciadas como observamos no parque, nas brincadeiras junto com o professor de Educação Física. Também, durante o período de nossa observação, esta criança ganhou uma cadeira adaptada especialmente para ela, permitindo que ela sentasse sem ter que ser contida de modo especial nas cadeiras normais já existentes em sala. Esta modificação e inserção de um objeto mais adequado às demandas da criança possibilitou que esta ganhasse maior autonomia quando sentada próxima a mesa, seja nos momentos de alimentação como de outras atividades como no desenhar e brincar com objetos sobre a superfície da mesa. Torna-se indispensável saber dos cuidados especiais que envolvem a educação desta criança para que, ao organizarmos as propostas pedagógicas para este grupo, tais indicações sejam observadas.

Com base em nossas observações e interações com as crianças e, segundo a professora, o grupo se caracteriza pelo uso e pela descoberta das linguagens, ou seja, as crianças se comunicam a todo o momento, demonstram alegrias, medos e angústias de várias maneiras: verbalmente, com choros, gritos, gestos, risos, abraços, através de desenhos, pinturas, canções.

\section{DAS LINGUAGENS NO GRUPO}

A linguagem que ficou mais evidente para nós entre as crianças ao longo do nosso período de observação participante foi a musical. Isto porque, em quase todos os momentos do cotidiano das crianças na instituição a professora utilizava a música como uma linguagem de expressão e comunicação, um instrumento de aprendizagem e de ludicidade, bem como uma "estratégia" para trocar de atividades.

Sobre a linguagem musical nos contextos formais de educação Lazzarin (2004) defende que o ensino da música é necessário para uma educação humanística, oportunizando o desenvolvimento integral da pessoa (LAZZARIN, 2004, p.16).

$\mathrm{Na}$ Educação Infantil é importante haver esse elo de ligação entre a música e as demais linguagens, pois observamos que as crianças respondem positivamente cantando e 
através dos movimentos do corpo quando a professora emprega a linguagem musical no trabalho com elas, mesmo quando a música cantada ainda não lhes é familiar. Ou seja, o encontro das crianças com melodias, canções e rimas desconhecidas nos pareceu que as instigava ainda mais a participar da proposta, despertava a sua curiosidade, as aproximava do "desconhecido" ampliando não somente seus repertórios musicais, mas os seus saberes sobre o vasto mundo.

A experiência com a arte [e assim, com a música], com a linguagem e com a história torna-se formativa, isto é, no encontro com o estranho, com aqueles que pensam de forma diferente, o homem reconhece sua finitude e amplia seus horizontes de compreensão. A idéia de formação é exatamente esta, de um movimento que o sujeito faz afastando-se de si para apropriar-se do mundo. Ao voltar do encontro com o outro, o sujeito reconhece o estranho com o familiar, volta modificado. Este movimento dialético em direção ao outro e de volta a si mesmo é constante e ininterrupto, é constitutivo de nosso estar-no-mundo (LAZZARIN, 2004, p.35-36).

$\mathrm{Na}$ direção do encontro das crianças com repertórios musicais desconhecidos, Ostetto (2004, p.50) coloca que "ninguém pode gostar do que não conhece". Assim, quanto mais as crianças tiverem garantido o seu direito ao acesso irrestrito a música de diversos gêneros, tempos, compositores e culturas, estaremos colaborando para que estas possam gostar de um amplo leque musical.

Ainda tratando-se do valor formativo que a música proporciona ao grupo observado na instituição, vale ressaltar que Lazzarin (2004) também fala sobre a crença no "poder mágico" da música sobre as pessoas fazendo que, com isso, elas se tornem mais sensíveis e mais humanas.

Afirmações do tipo "música é uma linguagem universal", "música é essencial para a formação integral" pressupõem a crença na possibilidade de a música conter virtudes que podem ser assimiladas por pessoas ou despertadas nelas quando ouvem. Este caráter inefável, que comunica algo que vai além das palavras, confere a música uma característica importante que lhe daria, segundo as "filosofias", um lugar de destaque no currículo, por possibilitar o acesso a um conhecimento diferente do verbal (LAZZARIN, 2004, p.41).

Por isso, trabalhar, organizar o cotidiano das crianças envolvendo a música é enriquecedor, é a possibilidade de ampliar os referenciais artístico-culturais dessas, assim como promover a sua formação sensível. 
A seguir, apresentamos alguns dos nossos registros onde fomos mapeando a linguagem musical entre as crianças, assim como a presença de outras linguagens, sendo algumas de modo mais intenso outras menos ${ }^{1}$.

\subsection{LINGUAGEM MUSICAL}

Quando a professora começava a cantar as crianças acompanhavam, dançavam, faziam gestos e sorriam. Isso ocorreu, por exemplo, quando estavam no parquinho, na hora do lanche, para resolver um conflito, por diversão, durante os momentos acompanhados diretamente pelo professor de educação física e mesmo quando brincavam com massinhas de modelar. Entre tantos registros desta dinâmica no grupo, apresentamos abaixo um ocorrido no dia 21 de maio de 2008:

As crianças estavam trabalhando, brincando com os animais junto com a professora e as auxiliares de sala. A professora mostrava um cartão com um animal desenhado e colorido e a criança tinha que adivinhar que animal era. Brincaram uns 20 minutos com esses cartões e depois, para trocar de atividade, a professora foi recolhendo os cartões cantando: Sendo em seguida acompanhada pelas crianças.

“Olé, olé

Olé, olé, olá

Arreda do caminho

Que a Bernunça quer passar" (Boi-de-mamão)

Gilberto (Giba), o professor de educação física, começa a tocar um pandeiro do corredor e as crianças ficam o esperando, pois sabem que hoje era dia de brincar com o Giba. Ele chega na cerquinha da sala e canta:

"Olé, olé

Olé, olé, olá..." (música do boi-de-mamão)

Gilberto canta e toca o pandeiro. Ele entra na sala e senta num cantinho com as crianças a sua volta e canta:

"O meu boi morreu

O que será de mim...” (Boi de mamão)

Depois canta:

\footnotetext{
${ }^{1}$ Relembramos ao nosso leitor que as pontuações feitas aqui, sobre as linguagens entre as crianças, são decorrentes da nossa semana de observação participante. Ou seja, são limitadas a um curto período de convívio entre as crianças, a professora e as bolsistas no cotidiano do NDI.
} 
"O sapo não lava o pé

Não lava porque não quer

Ele mora lá na lagoa

Não lava o pé

Porque não quer

Mas que chulé"

E começa outra música:

"Borboletinha, tá na cozinha

Fazendo chocolate

Pra vovozinha..."

Outra canção muito presente entre as crianças.

"Eu sou

Eu sou

Eu sou jacaré coio

Sacode o rabo, jacaré

Sacode o rabo jacaré coio"

(Registro de Observação - 21/05/2008 - Aluna-estagiária Samara)

As crianças parecem estar adorando, pois cantam junto, batem palmas e fazem gestos

(Registro de Observação - 07/05/2008 - Aluna-estagiária Elaisa).

Segundo Lazzarin, (2004, p.11) é comprovado que a maioria das pessoas concordam que a música desempenha, sem dúvida, papel importante em suas vidas e que certamente deveria ter um lugar garantido no currículo escolar. Por isso, o autor também afirma que a complexidade do fenômeno artístico musical extrapola as possibilidades compreensivas de disciplinas como matemática e português. No caso da Educação Infantil, esta também não deve entrar como meio para ensinar um determinado conteúdo disciplinar. Para a educadora musical Dulcimarta Lino (2001, p.68), a tônica do trabalho pedagógico com a linguagem musical no contexto da Educação Infantil “é possibilitar um ambiente de descoberta e revelação dos imaginários infantis, buscando a organização da forma e a conquista de outros possíveis a partir do fazer musical”.

\subsection{LINGUAGEM CORPORAL (GESTOS E DANÇAS)}

A linguagem corporal das crianças foi igualmente percebida em muitos momentos, pois as linguagens não aparecem estanques em nossas vidas, muito menos na infância. A linguagem corporal estava entre as crianças nas suas formas de dançar o boi de mamão, nos 
momentos descontraídos, empolgantes e desafiantes para as crianças vividos nas propostas organizadas pelo professor de educação física (sempre acompanhados pela professora e pelas bolsistas); caminhando, deitando, sentando, "correndo" onde igualmente evidenciamos uma multiplicidade de emoções. Do mesmo modo, a gestualidade das crianças veio à tona quando elas estavam no parquinho e nas brincadeiras por elas ali realizadas pelas crianças, na hora do lanche e nas brincadeiras em sala. Uma das vivências em que podemos perceber esta dinâmica entre as crianças evidenciando a expressão corporal destas, pode ser retomado no seguinte registro:

A outra brincadeira é a "chuva de bolinhas coloridas". O professor joga a cesta cheia de bolas para o alto e as crianças correm para pegar as bolas. Pegam e guardam na cesta novamente. O professor começa a jogar para o alto outra vez. Fazem essa brincadeira umas 5 vezes. Depois, ele fala que as crianças têm que jogar as bolas na professora, e todas fazem o que ele pede. Elas adoram e o professor Gilberto é muito divertido! Percebi que ele trabalha todas as partes do corpo das crianças: a criança pula, corre, senta, balança os braços, estica as pernas e gastam energia. (Registro de Observação - 07/05/2008 - Aluna-estagiária Samara)

Logo após, o professor começa outra brincadeira: a dos colchões. Vamos até uma rampa que tem perto do auditório, colocamos vários colchões encostados um no outro e as crianças, ao comando do professor começam a rolar. As auxiliares, a professora, eu e Elaisa (aluna-estagiária) ajudamos a segurar. O professor fala para imitar: um cão, gato, cobra, sapo e leão. As crianças fazem os movimentos o imitando e também fazem o som de cada animal. (Registro de Observação - 07/05/2008 - Aluna-estagiária Samara)

(...) presenciamos e dançamos junto com as crianças o boi-de-mamão. Elas fazem até coreografia. Depois, juntou com as outras turmas do módulo e ficamos todos lá na sala dançando. Tinha até pais olhando. Estava bem cheio! Mas estava muito divertido! (Registro de Observação - 08/05/2008 Aluna-estagiária Elaisa)

\subsection{LINGUAGEM PLÁSTICA}

As crianças trabalharam muito com a linguagem plástica. Para exemplificar isso, podemos citar: brincando com massinha de modelar, pintando a palma das mãos e carimbando em papéis para compor seus trabalhos, desenhando, colorindo, brincando com areia de fazer castelos, bolos de aniversário e docinhos. 
A professora vai terminar o trabalho que foi começado outro dia, que era de pintar a palma da mão das crianças e carimbar em uma folha com seu nome embaixo da marca da mão, pois Mirela e Lorena que faltavam terminá-los. Cris (a professora do grupo) também carimbou a sua mão (Registro de Observação - 08/05/2008 - Aluna-estagiária Elaisa).

Observando cada criança, percebi suas diferenças na hora de brincar com as massinhas de modelar, como por exemplo: Stella brincava em silêncio com as massinhas; Sofia brincava de médico com um brinquedo de plástico que estava na sala para ouvir o coração; João observava seus colegas e depois não resistiu e, começou a brincar de massinha também; Joaquim fazia bolinhas com a massinha; Rafael também brincava quieto de massinha e Manú (como é carinhosamente chamada pelos amigos e adultos) tentava pegar os potes de plástico distribuídos na mesa e começava a bater um no outro. Depois, Manú ficou olhando atentamente para Stella brincando de massinha. (Registro de Observação - 06/05/2008 - Aluna-estagiária Samara)

São 14h30min e as crianças continuam brincando com a massinha. Agora todos fazem pirulitos, bolos de aniversário e docinhos (Registro de Observação - 06/05/2008 - Aluna-estagiária Elaisa).

A professora pediu que brincássemos com as crianças enquanto ela trocava as fraldas de algumas, sugerindo que poderíamos brincar com as massinhas de modelar. Eu e Elaisa sentamos com as crianças em volta da mesa, demos um pouco de massinha (todas são da mesma cor rosa) para cada um, palitos de picolé, faquinhas de plástico e forminhas. Brincamos de juntar massinhas, fazer bolas, pirulitos, jacarés, docinhos, cobras e de cortar a massinha. (Registro de Observação - 08/05/2008 - Aluna-estagiária Samara)

\subsection{LINGUAGEM ESCRITA E ORAL}

Presenciamos mais momentos onde se fez presente a linguagem oral do que escrita, pois as crianças - nesta faixa etária - se expressam e significam o mundo de modo mais intenso por meio de outras linguagens. Este grupo está em plena fase de descoberta e construção de significados para as palavras mais corriqueiras da cultura a qual pertencem. Dos momentos que observamos, dois nos chamaram mais atenção em relação à linguagem oral das crianças: o primeiro refere-se à tentativa das crianças falarem quais eram os animais nos desenhos que a professora criou e a turma pintou. Elas reproduziam o som desses animais que lhes eram mostrados em cartões com desenhos colados e pintados pelas crianças. Entre os desenhos tínhamos o golfinho, o gato, o cavalo, o leão, o cachorro e a cobra. Mesmo as crianças falando as palavras faltando algumas letras, nós entendíamos perfeitamente seu esforço e o que desejavam comunicar. O segundo registro, refere-se ao 
momento que uma criança descobriu uma nova palavra para seu vocabulário, a palavra "meu". Citamos este fato, pois um dos objetivos do trabalho pedagógico da professora com este grupo de crianças era o de desenvolver e trabalhar as diferentes linguagens e significações destas entre as crianças ${ }^{2}$.

Mirela e Sofia sentaram do meu lado e ficamos ali vendo os animais. Depois, peguei um cartão do golfinho rosa e perguntei:

- Que animal é esse?

Mirela respondeu:

- É uma baeia! (sem o "L" mesmo)

Sofia repetiu:

- Baeia!

Eu disse:

- Baleia, muito bem! E que som esse animal aqui faz? (mostrei um gato).

- miauuuuuu! (respondeu Mirela)- (Registro de Observação - 07/05/2008 Aluna-estagiária Samara)

Estávamos brincando com as crianças com as massinhas de modelar, quando a menininha Stella começa a dizer que tudo era dela, só falava a palavra "meu" apontando para as massinhas, os jacarés e os pratinhos de plástico. Sofia começou a chorar, pois Stella havia pego o prato que ela estava brincando, então a professora falou:

- Ah! Aprenderam uma palavra nova, é? Essa palavra que é "meu" eu não conhecia. Não tinha aqui na sala ainda, Stella! Agora pega outro prato pra ela então, Clara" (Registro de Observação - 06/05/2008 - Aluna-estagiária Samara).

A partir dessa observação das ações e significações referente a palavra "meu" e suas palavras apostos acreditamos que essa criança já se apropriou diferentes conceitos, como: seu(a), nosso(a) entre outros. Um dos inúmeros objetivos da aquisição da linguagem oral é o de compreender e se fazer entender, saber diferenciar palavras e significados e entender em qual momento determinada palavra pode ser empregada. É aprender a expressar-se, a dizer a sua palavra, os seus desejos e sonhos, assim como estabelecer uma relação de diálogo com o outro.

\subsection{LINGUAGEM LITERÁRIA (NARRAÇÃO e CRIAÇÃO DE HISTÓRIAS PELAS CRIANÇAS E SEUS PROFESSORES)}

\footnotetext{
2 Esta informação nos foi dada pela professora do grupo, no momento em que conversamos sobre o planejamento pedagógico, a partir das nossas questões de observação previstas para a semana intensiva de estágio de observação participante no NDI.
} 
Não presenciamos - no limite de uma semana de observação - muitos momentos de narração de histórias infantis no grupo. A linguagem literária, as narrativas e criações de histórias, os contatos das crianças com o universo das histórias ocorreram quando as crianças pegavam algum livro de pano para ver as imagens exposto na sala ou na hora da entrada, quando as crianças sentavam em roda para ouvir a professora contar uma história. Ao conversar com a professora, ela comentou conosco que inventava e contava histórias na hora para as crianças, como por exemplo, aquelas envolvendo os elementos da natureza.

(...) o entrarmos na sala, a professora estava contando uma história sobre elementos da natureza, como animais, florestas, água, vento (inventada pela própria professora na hora) para as crianças: Sofia, Joaquim, Rafael, Manú e João. As auxiliares ainda não haviam chegado, por isso a volante Renata se ofereceu para ajudar a professora Cris (Registro de Observação - 06/05/2008 - Aluna-estagiária Samara).

Como falamos anteriormente, as crianças do grupo 3A tinham a forte presença da linguagem musical em seu cotidiano. Se compreendermos as canções enquanto narrativas, estas se aproximam dos possíveis significados das histórias entre as crianças pequenas.

A narrativa chega cedo à vida da criança, já em seus primeiros dias de vida. Chega através do padrão musical regular dos acalantos, que, como as histórias, se abrem e fecham nitidamente, contendo em si um mundo particular. Chega através das letras das cantigas que tantas vezes contam histórias, como O Cravo brigou com a Rosa, Ciranda Cirandinha, A Canoa Virou e Atirei o Pau no Gato, para ficar nos exemplos mais óbvios. Chega através das canções que marcaram a infância e a juventude da mãe e do pai que a embalam no colo, selecionadas de um arquivo pessoal de favoritas aprendidas também no rádio e na TV (GIRARDELLO, 2007, p.40).

Portanto, mesmo que não houvesse uma proposta sistemática da narração de histórias a partir de livros, as crianças tinham contato com as narrativas uma vez que contavam e ouviam histórias criadas "na hora" e cantavam a toda hora.

Quando retornamos à instituição, na oitava fase do curso, houve algumas mudanças que fez com que nosso estágio tomasse um rumo diferente do previsto.

Primeiramente, dentro do grupo 3A, as bolsistas de sala mudaram. Além disso, chegou uma menininha nova no grupo. Ela ainda estava em fase de inserção no grupo e a 
professora Cristiane estava tentando construir laços de significação, afeto, aceitação e companheirismo dela em relação ao grupo, da mesma forma que das demais crianças para com ela.

Além disso, o espaço físico do ambiente (sala de referência do grupo) era pequeno em relação à quantidade de adultos e crianças que o compartilhavam. Ficava desproporcional um grupo com cinco adultos (uma professora, as duas bolsistas e nós duas como estagiárias) e nove crianças. As crianças já não sabiam mais quem ouvir e a quem obedecer. As questões espaciais vieram a interferir no cotidiano de todos, crianças e adultos, sendo que numa tentativa de organizar a situação a professora pediu que nós não interferíssemos nas suas ações de comando, deixando assim apenas uma voz a ser seguida pelos meninos e meninas do grupo.

Em uma reunião com a coordenadora da instituição e nossa orientadora de estágio, foi decidido que, devido ao contexto apresentado no grupo $3 \mathrm{~A}$, nossa atuação junto às crianças não seria mais dentro dos limites deste grupo. Neste sentido, abriu-se um novo desafio para nós e para a própria estrutura do estágio supervisionado, uma vez que passaríamos a atuar com várias crianças de grupos diversos enfocando o brincar e modificações no espaço do NDI. Foi uma mudança repentina para nós e simultaneamente gerou insegurança e expectativa afinal, achávamos que iríamos desenvolver nosso estágio com um grupo o $3 \mathrm{~A}$, ficar em um único grupo e a partir daquele momento era preciso mudar nosso planejamento e o foco inicial.

Assim, acabamos construindo um projeto onde a proposta e atuação visava o trabalho com outros grupos onde o estágio também estava acontecendo. Desta forma, o projeto abrigava propostas voltadas aos grupos: 7, 3B e 6B, através de organização e proposição de espaços e tempos para as brincadeiras, bem como o apoio aos grupos em outras atividades previstas, por nossas colegas estagiárias, em seus planejamentos semanais. Assim, as propostas envolveram diferentes faixas-etárias e trabalhamos com diversas brincadeiras e modos de brincar.

Nossa intervenção baseou-se em dialogar com projetos desses grupos, a fim de ajudar a construir as brincadeiras que possibilitassem, instigassem o brincar, apresentando elementos e novas configurações em relação à utilização do espaço na instituição, a fim de enriquecer as brincadeiras, o lúdico e o imaginário infantil. Possibilitando e ampliando o 
contato das crianças com os brinquedos da instituição, a experimentação, a criatividade, o pensamento lógico e a expressão artístico- cultural.

Essa mudança só foi possível - aceita como uma proposta de estágio - porque o brincar e a brincadeira são fundamentais no desenvolvimento infantil e importante dentro do contexto da educação das crianças. Associa-se a isto o fato de que atuaríamos em espaços e tempos em que observamos não ter nenhuma intervenção sistemática, em especial, nos períodos de entrada e saída das crianças na instituição. Essa nova forma de trabalhar com as crianças abriu nosso diálogo com os outros grupos, suas dificuldades e um desafio para nos inserir em diferentes planejamentos e faixas etárias. Apesar da insegurança e dificuldades encontradas, essa proposta da orientadora e coordenadora da instituição nos proporcionou a criação e o desenvolvimento de uma ação intencional baseada no brincar e na brincadeira. Uma temática crucial para nossa formação como professoras e igualmente para a constituição do sujeito criança.

Nosso planejamento partiu então das propostas já organizadas e que vinham sendo desenvolvidas pelas demais estagiárias, e foi construído buscando ampliar as experiências das crianças de modo significativo e contextualizado. Assim, nos grupos foram sempre organizadas propostas tendo em vista as seguintes indicações:

Grupo 7: Jogos de percurso, criação do livro, teatro, histórias, caça ao tesouro.

Grupo 6B: Folclore, brinquedos e brincadeiras folclóricas, fantoche, cultura popular, origami e escultura de argila.

Grupo 3B: Vida marinha, elementos envolvendo a cultura da Ilha de Florianópolis, histórias, canções, brincadeiras, teatro e trabalhos com texturas.

Em conjunto aos trabalhos dentro dos grupos, nossa intenção era a de modificar o espaço do cotidiano da instituição com o objetivo de criar outras possibilidades para o brincar das crianças em geral.

Tendo o brincar ou as brincadeiras como centrais em nosso projeto, é preciso dizer que compreendermos o "brincar" o ato lúdico que a criança desenvolve podendo imaginar elementos diversos estando presente ou não na realidade. A criança ao brincar pode ser o que ela desejar naquele momento, sem limites para a imaginação. Para isso, depende muito da cultura que essa criança está inserida, por exemplo: uma criança pode brincar de ser a "mãe" de suas bonecas seguindo o modelo que ela possui e tem em casa ou o que ela 
imagina ser uma mãe. A criança também pode ter um cabo de vassoura na mão e imaginar que é o seu cavalinho, e assim por diante. O brincar é colocar a imaginação em ação (FANTIN, 2000, p. 85)

Segundo os estudos de Mônica Fantin (2000) sobre as brincadeiras infantis, tendo por base no referencial teórico da psicologia sociocultural - entre outros -, ela afirma que:

Para Vygotsky, as crianças pequenas experimentam desejos impossíveis de serem realizados imediatamente e para resolver esta tensão a criança envolvese num mundo imaginário onde os desejos não realizáveis podem ser realizados. O brincar da criança seria, então, a imaginação em ação. No brinquedo a criança cria a situação imaginária, que para o autor pode ser considerada como a característica definidora do brinquedo e não apenas um tributo dele, pois na situação fictícia a imaginação pode ser o caminho para a abstração (FANTIN, 2000, p. 85).

Dentro desta perspectiva, começamos nosso primeiro trabalho com a modificação de uma casinha de bonecas existente na instituição. Nossa intenção era a de torná-la primeiramente como a casinha de doces da história de "João e Maria" e, futuramente agregar objetos a essa casa que lembrassem outras histórias conhecidas pelas crianças para ampliar seu imaginário, oferecendo novos objetos para a atividade imaginativa como num conto infantil. Isto porque, é através da manipulação dos brinquedos, no brincar que a criança imagina a forma ou a maneira que ela gostaria que aquele brinquedo tivesse, podendo nestas atividades, criar novos significados para os brinquedos porque é na brincadeira que o objeto "perde" sua força determinadora e torna-se o que a criança quiser. Assim, o brinquedo é sempre um suporte para a brincadeira, um empolgante objeto para fazer fluir o imaginário das crianças, sendo que sua função não é a de determinar a brincadeira ou seu conteúdo, mas o de "despertar imagens que permitirão dar sentido a essas ações (das crianças sobre o objeto), sendo o brinquedo um fornecedor de representações manipuláveis" (FANTIN, 2000, p. 58).

A casinha também foi o cenário para narrar, contar histórias para as crianças, para que estas criassem suas próprias histórias. O trabalho ali desenvolvido buscou valorizar os encontros com o outro através da contação de histórias, e a troca narrativa como espaço de construção da comunicação e produção cultural, como coloca Girardello (2007, p. 39). 
Com este novo cenário para brincar e narrar histórias, acabava também por contribuir na aquisição da linguagem pelas crianças, pois como coloca Kishimoto (2002, p.148):

O brincar também contribui para a aprendizagem da linguagem.A utilização combinatória da linguagem funciona como instrumento de pensamento e ação. Para ser capaz de falar sobre o mundo, a criança precisa saber brincar com o mundo com a mesma desenvoltura que caracteriza a ação lúdica (KISHIMOTO, 2002).

Segundo Girardello (2007) a criança, que tiver contato com a linguagem terá também contato com a narrativa, dentro do contexto educativo (creches e pré-escolas) é importante garantir a vivência narrativa, pois esta contribui para o desenvolvimento de pensamento lógico das crianças e também de sua imaginação. A autora, também define a narração como uma conspiração pois:

Durante a narração, a troca não ocorre apenas no plano da linguagem, mas também através do ar: pelo sopro compartilhado em que vibra a voz de quem fala no ouvido de quem escuta, pelo calor físico gerado pelos gestos de quem conta e de quem reage pela vibração motriz involuntária - arrepios, suspiros, sustos - causada pelas emoções que a história desencadeia. (GIRARDELLO, 2007, p. 42)

Quando organizamos este espaço, bem como os momentos de narração de histórias ali promovidas, tínhamos como apoio teórico as idéias de Maria Rita Kehl (2006, p.17), que escreveu o prefácio do livro de Diana e Mário Corso, chamado "As fadas no divã: psicanálise nas histórias infantis”. Kehl (2006, p.17) diz que, segundo os autores do livro, não faz muita diferença se a história é passada ou contemporânea, pois "a criança ainda não delimitou as fronteiras entre o que é existente e imaginoso, entre o verdadeiro e o verossímil". A autora ainda afirma que "todas as possibilidades de linguagem lhe interessam [à criança] para compor o repertório imaginário de que ela necessita para abordar os enigmas do mundo e do desejo" (KEHL, 2006, p.17).

As crianças de hoje continuam interessadas no mistério, sendo fascinadas por tudo que desperte o medo, que é uma das sementes privilegiadas da fantasia e da invenção. É em função do medo que desenvolvemos a curiosidade e a coragem. As histórias infantis 
sempre incluem elementos assustadores que ensinam as crianças a enfrentar em seus medos (KEHL, 2006, p.17).

Assim, nossa intervenção na casinha não se limitou, não buscou colocar em evidência somente imagens e brinquedos que despertassem sensações, emoções confortantes, mas também, na nossa cultura são signos que constituem o universo de bruxas e vampiros, como o gato preto e morcegos. Assim, a casa no parque foi transformada em um cenário que abrigava, que convidava as crianças a brincarem com elementos que iam do pirulito, balas e bolos gigantes e coloridos até morcegos, aranhas e poções mágicas ou mesmo, garrafas de veneno, como algumas crianças disseram.

Segundo Fantin (2000, p. 91) o material, os objetos e brinquedos que disponibilizamos às crianças tem importância fundamental, sendo que sua qualidade e seu tema vão estimular a criança a atuar em diversas direções. Cabe, portanto, ao educador não só escolher o material, mas também observar às preferências, os interesses, as atividades das crianças de forma a possibilitar alterações no material e em sua disposição, quando isso se fizer necessário.

Ainda de acordo com Fantin (2000), é fundamental que os professores(as) da educação infantil organizem o espaço, os materiais para as crianças brincarem, caso contrário "a brincadeira não acontece, pois é na relação entre objeto - imagem -significado - ação - regra que a brincadeira se constitui como tal” (FANTIN, 2000, p. 92).

As imagens empregadas para criar um cenário fabuloso, que instigasse a imaginação, a curiosidade e a brincadeira entre as crianças, foram frutos de pesquisas na internet, livros infantis e revistas, a utilização de materiais como: jornal, E.V.A, tinta, verniz, papel celofane, papel laminado, cola, lantejoulas, garrafas, cordões, fitas, entre outros. E para as atividades realizadas nas salas de cada grupo ou em outros espaços fechados na instituição, buscamos os materiais necessários para a sua realização na própria instituição, além de levar músicas e o aparelho de som próprio.

\section{PLANEJAMENTO}

Nosso planejamento de estágio foi organizado de uma maneira que todos os grupos já citados participassem. 
Para isso, tivemos reuniões quinzenais com a coordenadora da instituição e com nossa professora-orientadora de estágio para discutirmos sobre o planejamento proposto. Além disso, semanalmente nos reuníamos com as estagiárias dos grupos a serem trabalhados a fim de combinar as atividades e horários das mesmas. Cada dupla era responsável por enviar seu cronograma de atividades para que pudéssemos fazer nosso planejamento.

A primeira semana de estágio, realizada entre os dias 08 a 10 de setembro de 2008 , foi a mais complicada, pois não foi possível seguir exatamente o planejamento que fizemos. Isso porque, ficamos aguardando o planejamento dos outros grupos para poder montar o nosso, pois gostaríamos de conciliar os horários em que as crianças não estivessem em sala para participarem das brincadeiras em espaços abertos.

Quando não estávamos realizando brincadeiras com os grupos nos dedicávamos a confecção de materiais, brinquedos e a decoração para a casinha na sala de artes da própria instituição.

Essa primeira semana de estágio também nos serviu como um "alerta" em questão de reserva de materiais para nossas propostas, para a confecção de materiais, para aprender a calcular o tempo destinado para cada brincadeira; considerar que nossas propostas podem não ser aceitas pelas crianças e assim, procurar ter sempre um plano "B", uma segunda proposta e outras estratégias de ação enfim foi um aprendizado muito significante para a continuidade do estágio.

A partir destes acontecimentos e sua posterior avaliação, nas outras semanas, conseguimos realizar as atividades do planejamento conforme o combinado. As estagiárias dos outros grupos nos forneceram seus planejamentos, o que fez toda a diferença na hora de elaborarmos o nosso e o desenvolvermos com as crianças.

Das brincadeiras que realizamos com os grupos de estágio mostraremos a seguir algumas que nos foram mais significativas.

\section{BRINCADEIRA: “PEIXINHOS E TUBARÕES” - GRUPO 3B}

FAIXA ETÁRIA: UM ANO E SETE MESES A DOIS ANOS E SETE MESES $(08 / 09 / 08)$ 


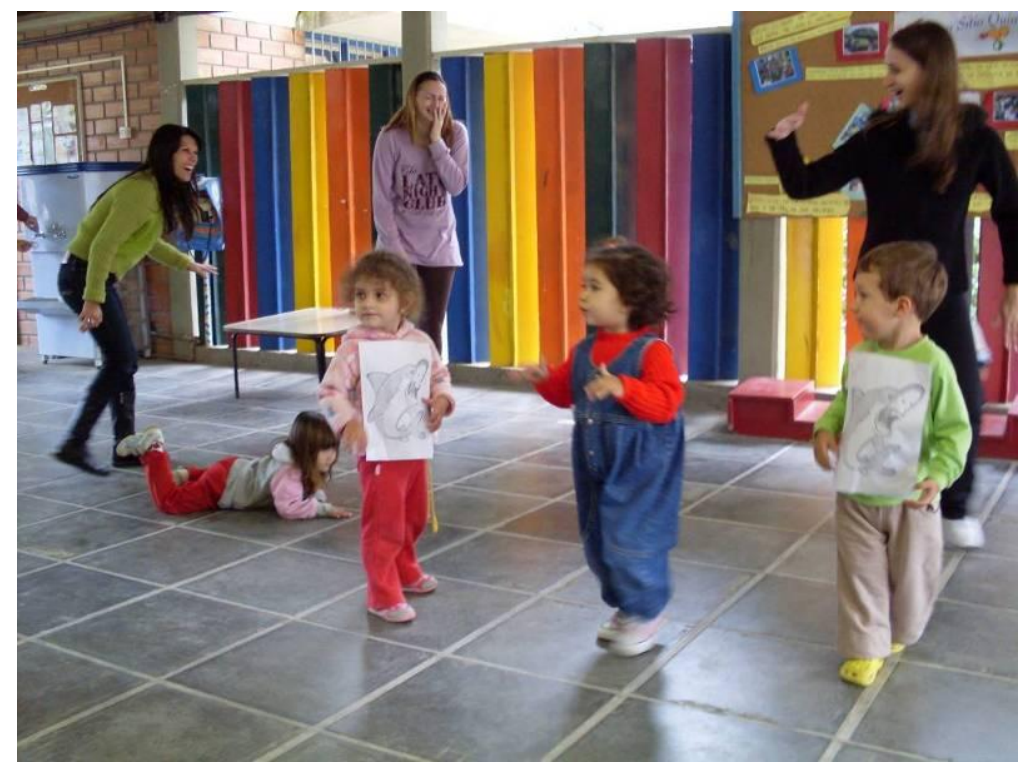

Com o grupo 3B, realizamos a brincadeira de "Peixinhos e tubarões" no saguão de entrada da instituição da seguinte forma: separamos a turma em dois grupos, um era somente "tubarão" e o outro grupo eram os "peixes". Colamos uma folha com a imagem de um tubarão na roupa das crianças com fita adesiva para identificar quem seriam os tubarões, agindo igualmente para quem seriam os peixinhos. Esta organização revelou um detalhe importante que não deve ser repetido: o papel com a fita adesiva não segura por muito tempo a folha sobre a roupa.

A dinâmica da brincadeira era a seguinte: quando o som diminuísse, todos do grupo (peixes e tubarões) deveriam "nadar" calmamente pelo espaço de acordo com o ritmo da música. Quando a música aumentasse, os tubarões deveriam correr, nadar muito rápido, para pegar os peixinhos. Com isso, as crianças corriam por todos os lados fugindo dos que eram tubarões. Quando um tubarão pegasse um peixinho (apenas encostando e dizendo que pegou) a criança-peixinho deveria parar de correr. Depois, as crianças trocavam os papéis e recomeçavam a brincadeira novamente.

Em outra oportunidade, realizamos novamente a mesma brincadeira (pois as crianças adoraram), mas dessa vez, com coletes que as identificassem como "peixes e tubarões". Foi muito mais fácil e divertido. Além disso, em relação a primeira vez que brincamos, nesta $2^{a}$ tínhamos uma melhor delimitação do espaço para a brincadeira, o que 
permitiu que as crianças e adultos "nadassem", num mesmo espaço com maior clareza dos papéis, quando e onde os tubarões apanhavam os peixinhos .

Nas brincadeiras organizadas (espaços, tempos, brinquedos ou outros suportes para a ação lúdica) pelos adultos, neste caso, as estagiárias, constitui-se "num espaço em que as crianças [puderam] compartilhar e confrontar suas concepções através da interação com o objeto e entre sujeitos" (FANTIN, 2000, p. 79).

Ao brincarem juntos (na brincadeira de "Peixinhos e tubarões"), estagiárias (outros adultos) e crianças, foram se conhecendo, se desenvolvendo como sujeitos sociais e culturais, interagindo, ampliando as suas dimensões afetivas, cognitivas, estéticas e culturais. Associa-se a estas questões, o fato de ser fundamental, entre as crianças pequenininhas (grupo 3B), que o adulto integre a brincadeira de forma a assegurar que esta vá aos poucos, aparecendo de modo independente. Segundo França (1990 apud FANTIN, 2000, p.98), a presença do adulto na brincadeira deve ser como um:

Elemento integrante das brincadeiras, ora como observador e organizador, ora como personagem que explicita, questiona e enriquece a trama, ora como elo de ligação entre as crianças e objetos - sendo assim um elemento mediador entre as crianças e o conhecimento (FANTIN, 2000, p. 99).

BRINCADEIRA: "PESCARIA" - GRUPO 3B - (15/09/08)

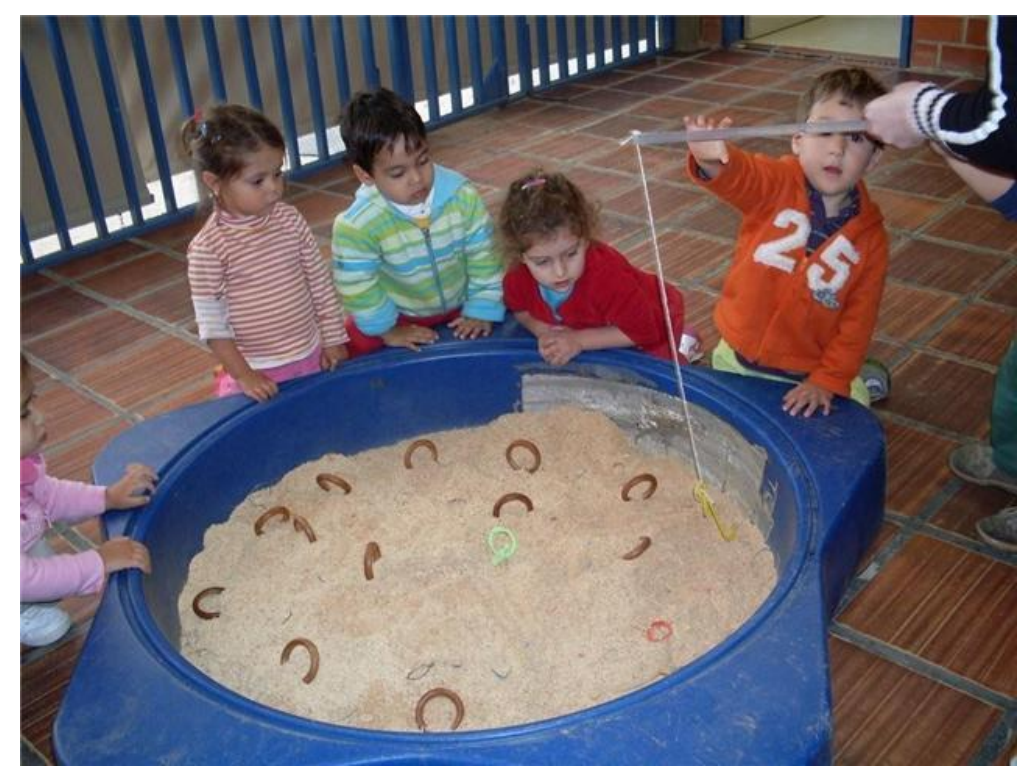


Também com as meninas e meninos pequenos do grupo $3 \mathrm{~B}$, fizemos a pescaria no solário da instituição, uma pescaria com fundo musical. Primeiro, mostramos às crianças como poderíamos brincar com os objetos ali dispostos e estas, atentas a tudo, demonstravam muita curiosidade e pareciam estar empolgadas com a pescaria. Os peixes que estavam escondidos, submersos "nas águas" (na areia) calmas, eram coloridos e todo o material era da própria instituição. Não demorou muito para que as crianças entrassem na brincadeira e não queriam mais parar de pescar. Percebemos que as crianças, no final da brincadeira, queriam pegar os peixes da areia com as próprias mãos e não queriam mais usar a vara de pescar. Elas espalhavam a areia, tiravam os peixes, mostravam umas para as outras e os escondiam novamente.

\section{BRINCADEIRA: BOLICHE - GRUPOS 6B E 7 - (10/09/08)}

FAIXA ETÁria dO GRUPO 6B: DE QUATRO ANOS E SETE MESES A CINCO ANOS E SETE MESES DE IDADE.

FAIXA ETÁria do GRUPO 7: DE CINCO E SETE MESES A CINCO ANOS E ONZE MESES DE IDADE

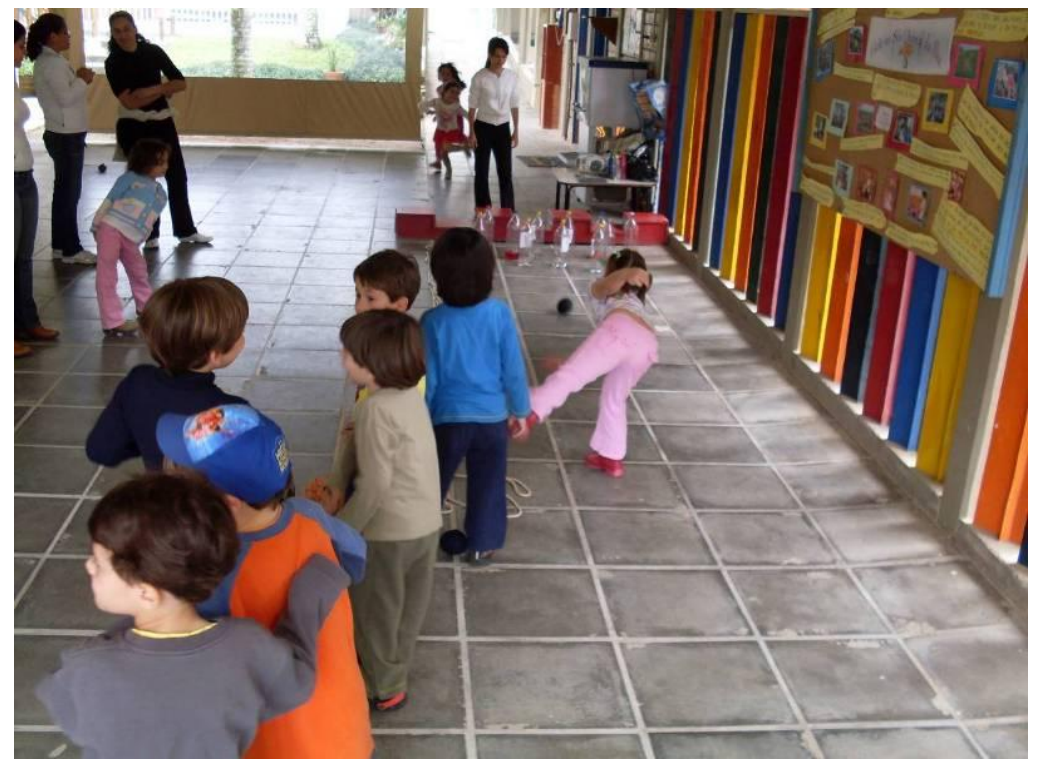


Ao falar das relações entre o espaço externo da instituição e as brincadeiras infantis, Fantin (2000, p. 208-209) explicita que tão importante quanto estruturar o espaço interno, as salas de referências dos grupos, é estruturar o parque, o hall de entrada, os corredores, etc. Uma organização que visaria torná-los o mais agradável possível, o mais instigante e propulsor da ludicidade, da imaginação e da brincadeira entre as crianças.

Considerando as indicações de Fantin (2000) expostas acima e, percebendo que o espaço do saguão de entrada da instituição poderia ser organizado para o brincar das crianças, nele promovemos diferentes brincadeiras, entres elas, a brincadeira de boliche.

$\mathrm{Na}$ brincadeira de "boliche com garrafa pet", enumeramos as garrafas para as crianças identificarem quais caiam, ou mesmo verem suas pontuações, como algumas fizeram. Além disso, as garrafas continham líquidos coloridos no seu interior, também para facilitar a identificação e para a mesma não ficar muito leve e cair facilmente.

Primeiro, demarcamos o local que faríamos a brincadeira com uma corda no chão. Explicamos a brincadeira e organizamos a fila. Também colocamos músicas infantis diversas neste espaço tempo e, enquanto as crianças esperavam a sua vez para jogar na fila, elas dançavam na fila (e em outros espaços do hall).

No começo, pensamos que não viriam tantas crianças para brincar, pois elas estavam entretidas, brincando nos diferentes parques da instituição. No entanto, aos poucos foram chegando, chegando e uma criança foi chamando a outra. Quando vimos, muitas crianças de diferentes grupos já estavam jogando boliche conosco.

Ficamos brincando com as crianças até a hora de voltarem para as suas salas de referência. Percebemos que as crianças gostaram bastante dessa brincadeira e respeitaram umas as outras e também as regras do jogo. Também tivemos a presença de alguns pais no local, mesmo que por um curto espaço de tempo. A presença destes, como observadores e ao mesmo tempo, incentivadores dos seus filhos e outras crianças, acabou se revelando uma importante forma de envolver pais e crianças numa brincadeira de curta duração no interior da instituição.

\section{BRINCADEIRA: “DANÇA DA CADEIRA” - GRUPOS 6B E 7 (16/09/08)}




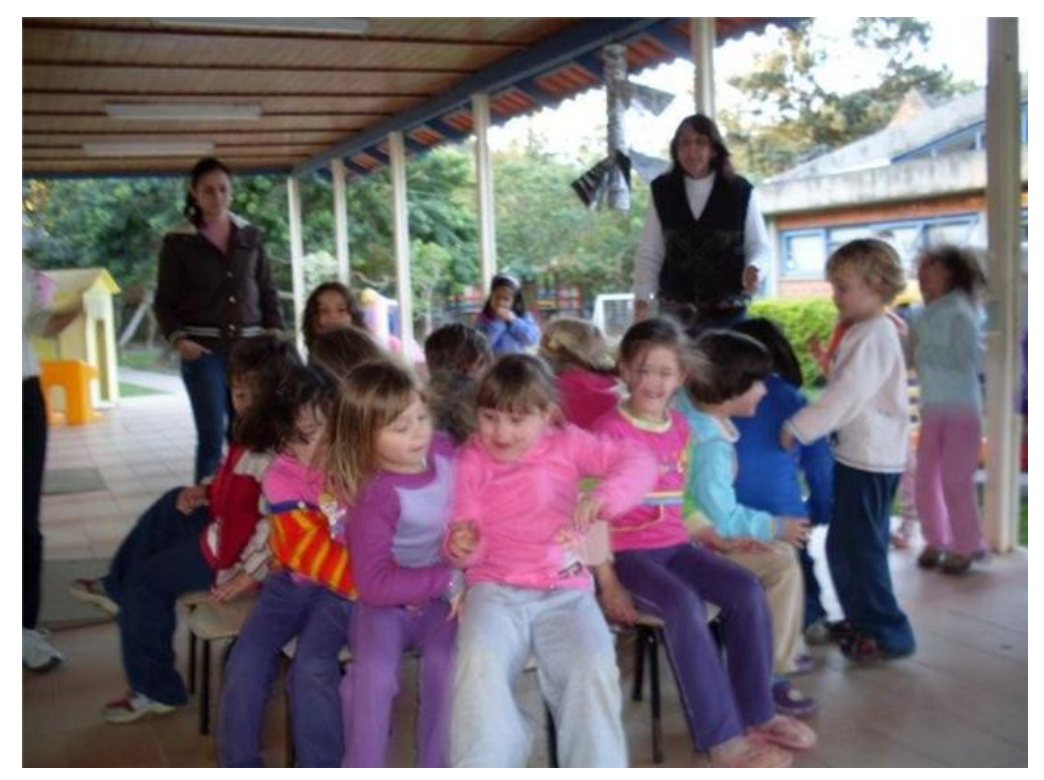

Na hora marcada, fomos até a entrada da sala do grupo 6B convidá-los para brincar de dança da cadeira. As estagiárias do grupo já haviam comentado que iríamos brincar com elas. Como o grupo 6B estava trabalhando com o folclore, a música escolhida foi sobre o boi: “Toada do boi Bumbá”, também cantada, entoada pelas crianças em sala.

Quando chegamos, entramos na sala para explicar como seria a brincadeira. As crianças nos escutaram atentamente e após, cada uma pegou a sua cadeira para participar da brincadeira. As crianças e nós organizamos as cadeiras na parte coberta em frente à sala do grupo. No momento que juntamos as cadeiras para saber quantos participariam, várias crianças do grupo 7 também quiseram participar e assim, unimos dois grupos numa mesma brincadeira. As professoras e estagiárias ficaram ao lado dançando e observando. Juntou muita gente! As crianças que iam saindo da brincadeira torciam pelas outras. Foi muito divertido e interessante, pois conseguimos juntar, na mesma brincadeira, dois grupos de crianças com idades diferentes.

Percebemos a importância que tem o brincar para as crianças, envolvendo diferentes faixas-etárias e grupos diversos. Segundo Antônio Leal (2000, p. 100) “a brincadeira introduz a criança no corpo social é ali, [...], onde ela também irá buscar o reconhecimento de seu corpo, através principalmente do toque corporal. A criança, pela brincadeira, irá construindo as suas afetividades". 


\section{BRINCADEIRA: “EXPRESSÃO CORPORAL” - GRUPO 7 (17/09/08)}

Fomos até a sala do Grupo 7 e, quando fizemos um sinal para Nicole e Deusa (estagiárias do grupo) que estávamos indo para o auditório conforme o combinado, as crianças nos viram e imediatamente se alegraram. Ao chegarmos mais próximas da sala, as crianças logo nos perguntaram se iríamos brincar com elas naquele dia. Como nossa resposta foi positiva, elas passaram a gritar:

- Eeeeeeeee! Vai ter brincadeira!

Assim, falamos para as crianças que depois que elas terminassem o lanche estaríamos as esperando no auditório. Para nós, como estagiárias, esta reação das crianças foi muito gratificante e significou uma grande conquista, nos ajudou a perceber como as crianças estavam valorizando o nosso trabalho, se identificavam com o mesmo, que gostavam de estar conosco e de participar das brincadeiras que realizávamos em conjunto.

Terminado o lanche, lá estávamos todos nós para "brincar no palco" do auditório do NDI. Nossa proposta para o grupo que estava as voltas com os preparativos e ensaios para a dramatização da peça teatral por eles escrita, envolvia exercícios de expressão corporal. Tais exercícios devem ser compreendidos, segundo elas próprias definiram: uma brincadeira. Esta brincadeira (exercícios de expressão corporal) requer, daquele que a conduz seja o(a) professor(a) ou, no nosso caso, as alunas-estagiárias:

Consignas sedutoras que convidem as [crianças] a embarcar no imaginário. Você não dará mais o que fazer imperativamente: preencham as lacunas, façam o dever, calem a boca ou sentem direito. Não se trabalha sobre um aprender repetido - é sobre a descoberta, é sobre o novo que indagamos, mesmo que repitamos um certo jogo. Um jogo pode ter uma consigna repetida, mas o fazer será sempre diferente (LEAL, 2000, p. 93).

Quando o grupo chegou, colocamos para ele que as brincadeiras daquele dia talvez os ajudassem no ensaio do teatro. No entanto, também explicamos ao grupo que estas brincadeiras, quando realizadas antes dos ensaios teatrais são igualmente denominadas como exercícios de expressão corporal. Eles escutaram com atenção, e depois, levantaram as mãos e fizeram muitas perguntas, além de contar que alguns dançavam, outros faziam ginástica olímpica, entre outros comentários. 
Assim, baseadas nas idéias de Antônio Leal (2000, p 100), quando ele menciona que para desenvolver uma atividade corporal é necessário "trabalhar com movimento: deitar, levantar, cair, levantar de novo, correr, caminhar, engatinhar - eis por onde começar um trabalho corporal simples", organizamos as brincadeiras para brincar com o grupo.

Para nos aquecer, Elaisa colocou a primeira música e nos convidou em roda a começarmos sentir cada parte do corpo, mexendo-a de acordo com o ritmo da música. Como a música falava sobre "mandar a preguiça embora", as crianças cantavam e simultaneamente faziam os movimentos indicados.

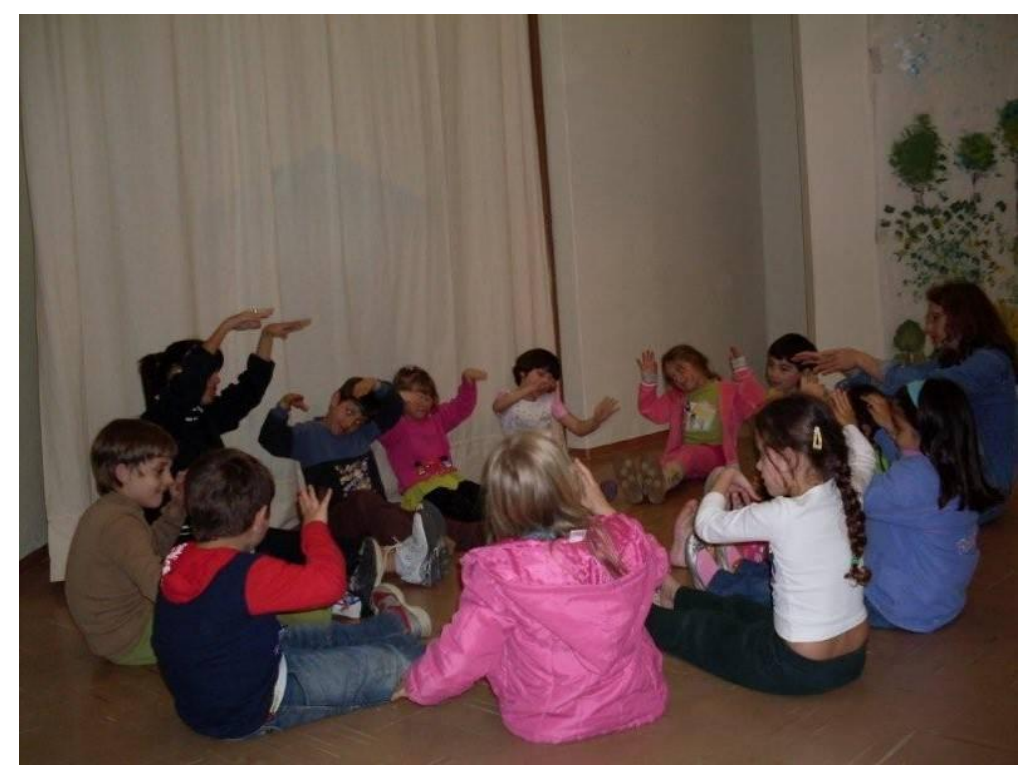

Na seqüência, nos deitamos como se estivéssemos na hora de dormir. 


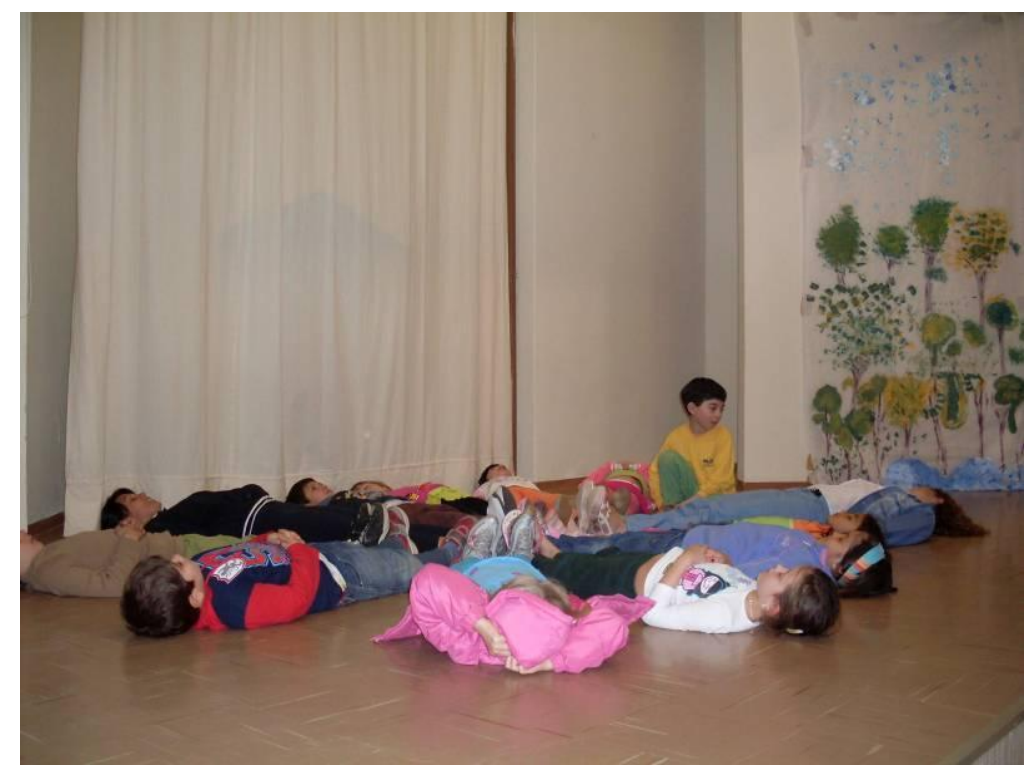

Fechamos os olhos por alguns segundos e, quando a música começou a ficar mais agitada fomos levantando e imaginando estar em uma floresta, sendo cada criança, o bicho que quisesse. Imitamos leão, cachorro, gato, pássaro, galinha e elefante um verdadeiro zoológico apareceu sobre o palco.

Logo após, distribuímos um tecido colorido para cada criança e explicamos que "pintaríamos" as paredes, o teto e o chão do palco com o tecido que tinha virado pincel. Levantamos primeiro um braço, depois o outro, pintamos cada parte do palco. Tudo que fazíamos, elas faziam também. Não paravam de olhar e fazer igual!

Com uma música mais agitada, era hora de atirar o tecido para cima e apanhá-lo com as partes do corpo indicadas por nós, como: mãos, pés, com um pé só, uma mão só, boca, bumbum, pernas, entre outros.

Ao final, no relaxamento, colocamos uma música mais calma. Solicitamos que todas as crianças deitassem sobre o palco, esticando as pernas e braços. Alongamos, alongamos e terminamos a atividade. 


\section{FOTOS DO TRABALHO REALIZADO NA CASINHA:}

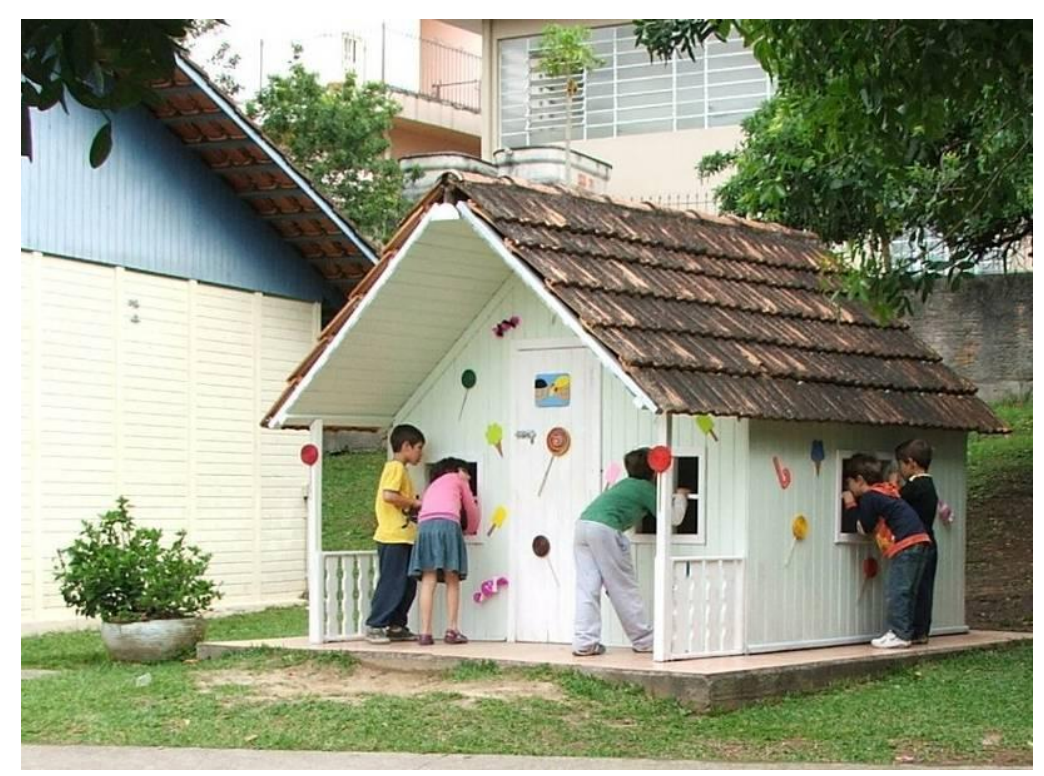

Casinha pronta, as crianças estão curiosas para saber o que tem dentro dela 29/09/08

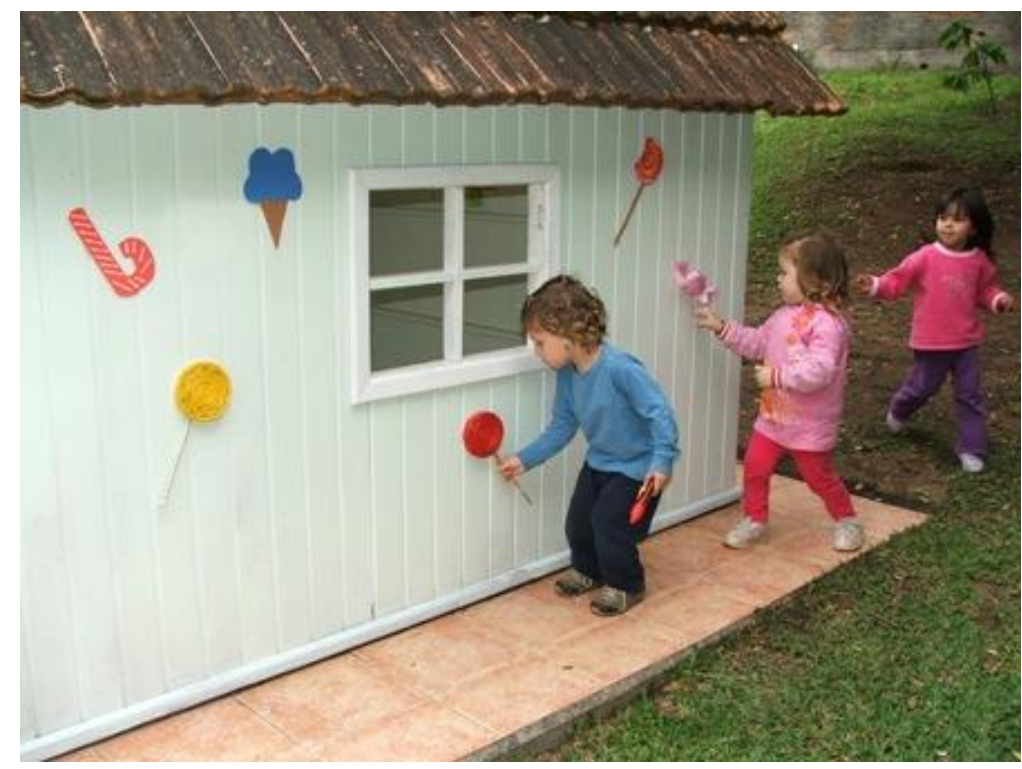

Grupo 3A conhecendo e "experimentando" a casinha 29/09/08 


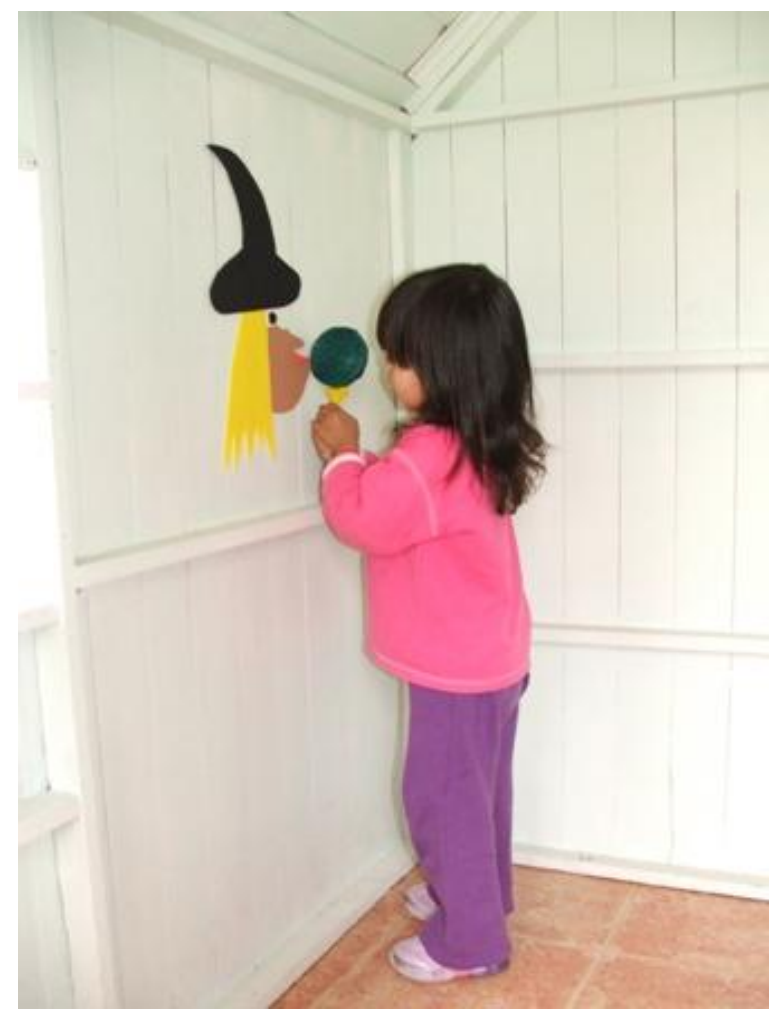

Mirela do Grupo 3A está oferecendo um pirulito a Bruxa. 29/09/08

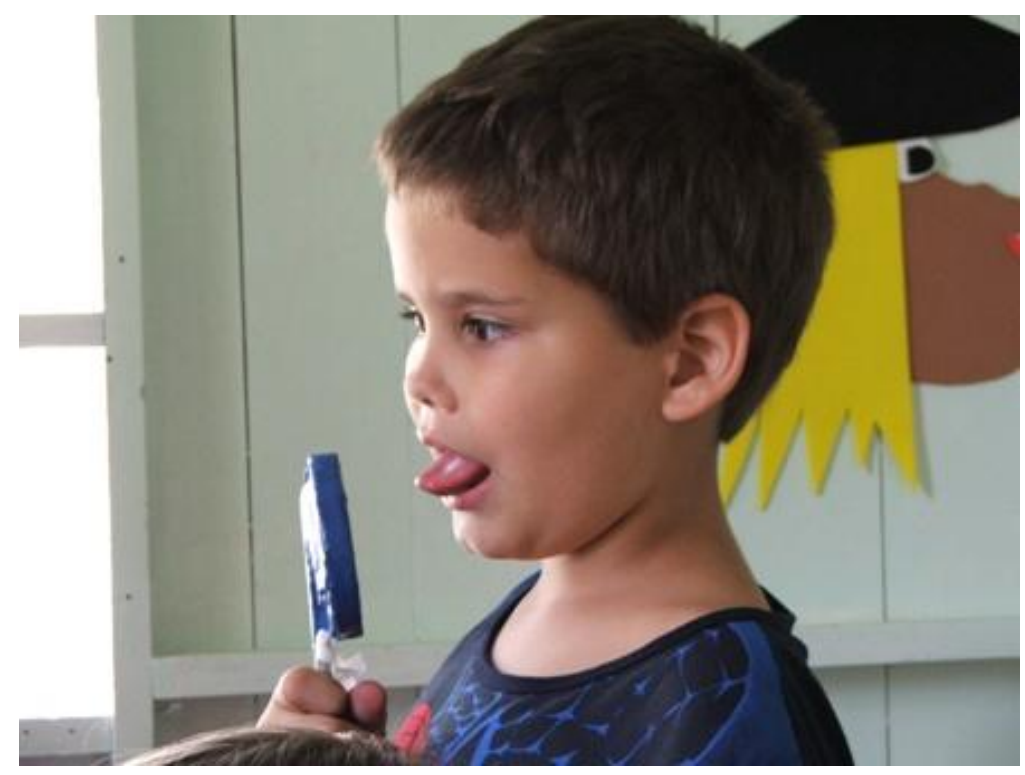

Menino do grupo 7 finge estar saboreando o pirulito enquanto houve uma história de sua coleguinha 29/09/08 


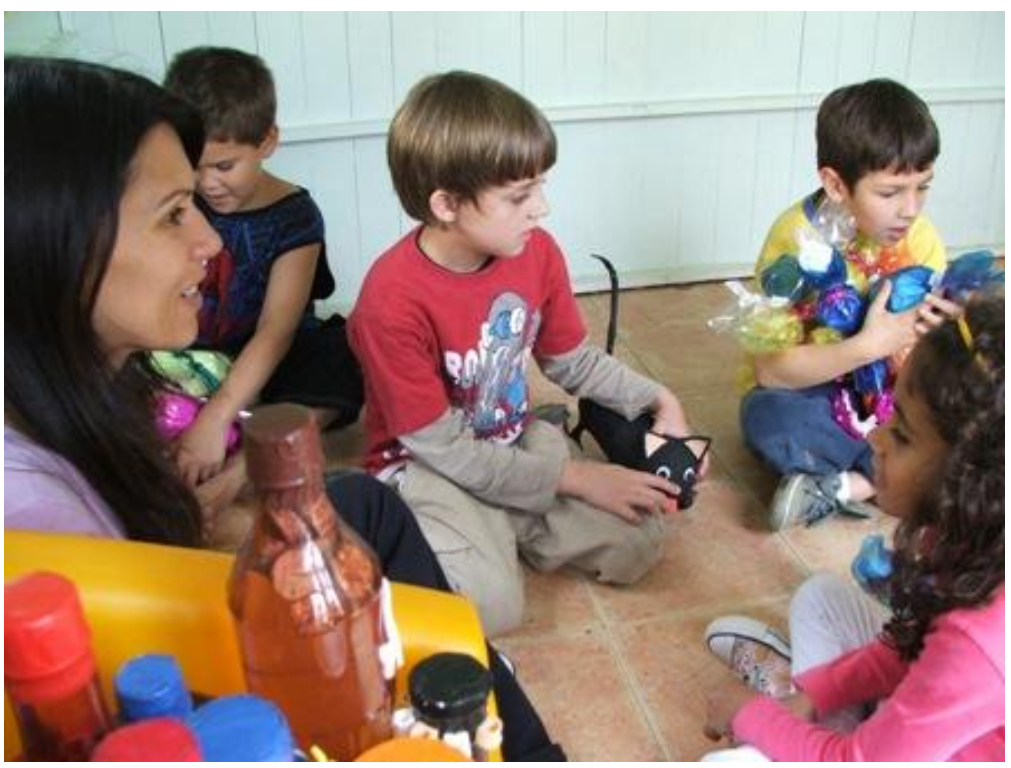

O Ambiente incentivou uma roda de histórias, todas as crianças presentes queriam contar uma 29/09/08

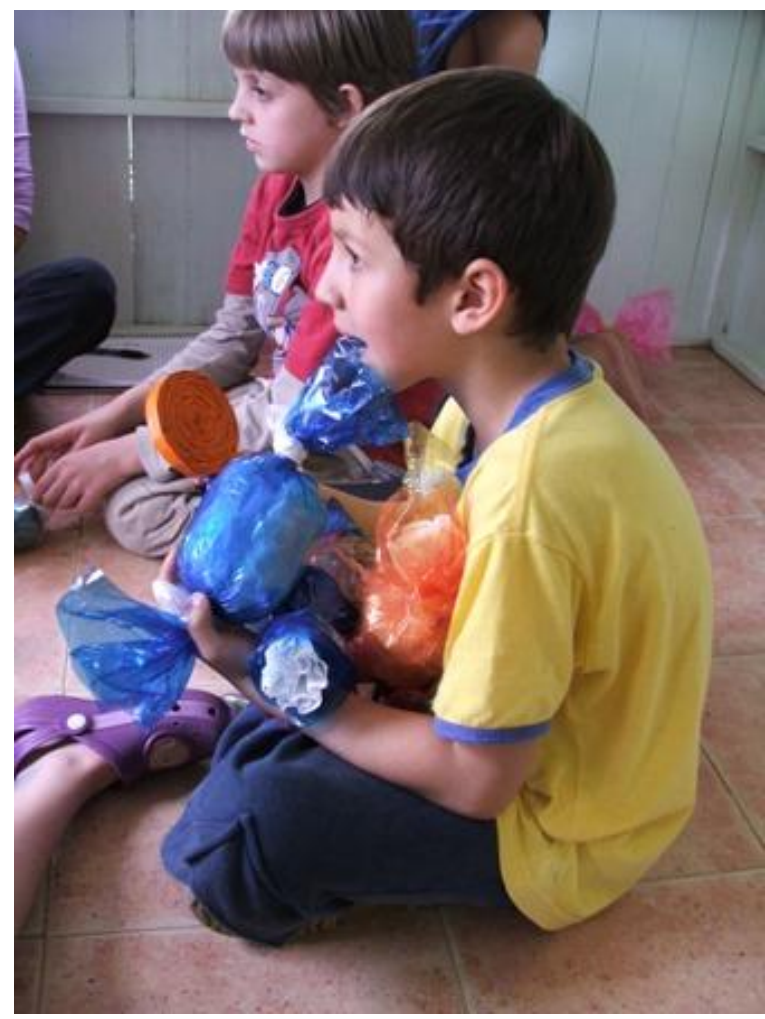

Crianças do Grupo 7 brincando com os "doces" e ouvindo histórias de coleguinhas 29/09/08 


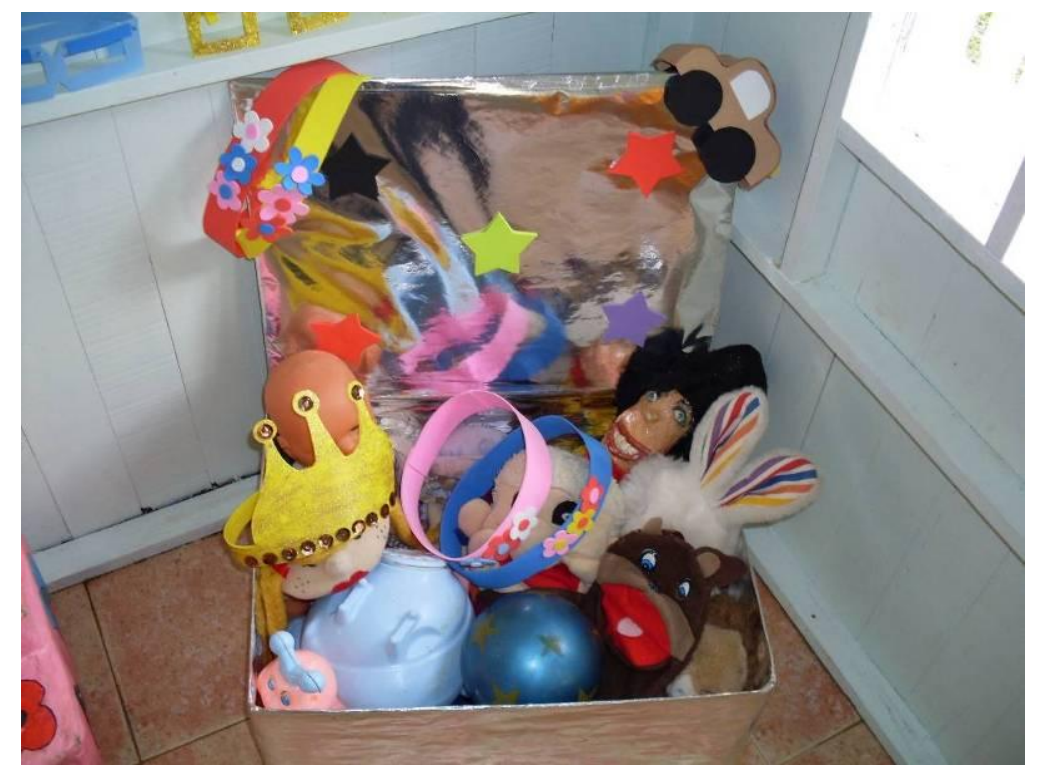

Material confeccionado: caixa de brinquedos cheia 29/09/08

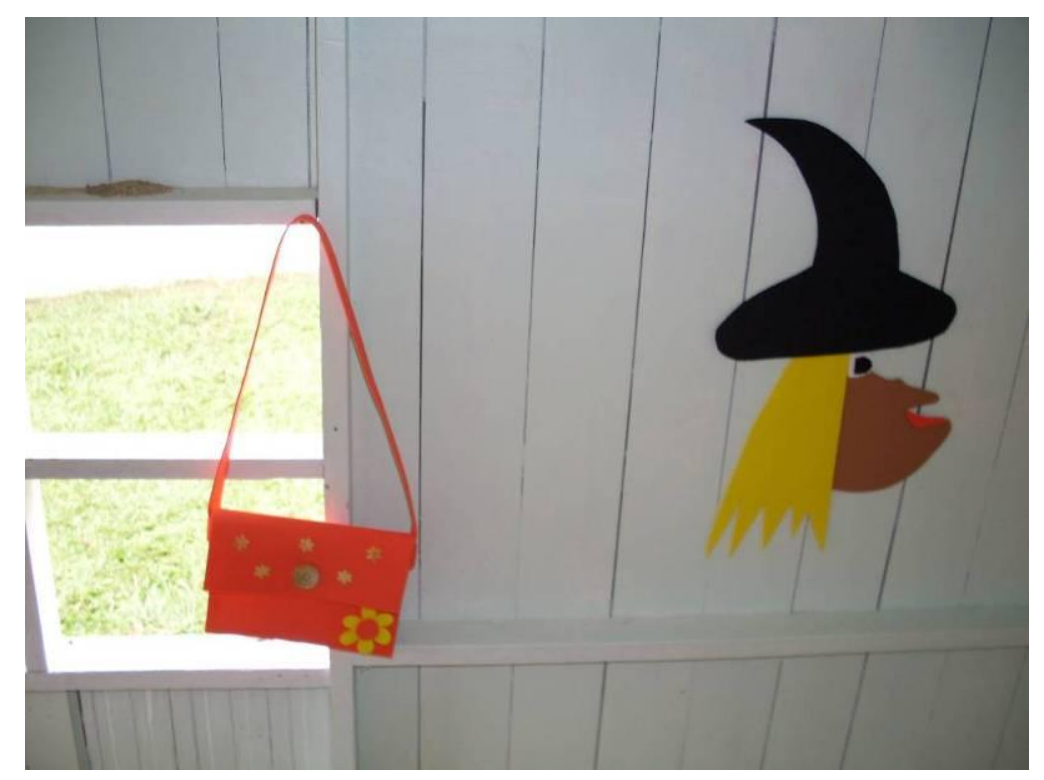

Material confeccionado: Bolsa e imagem da bruxa 29/09/08 


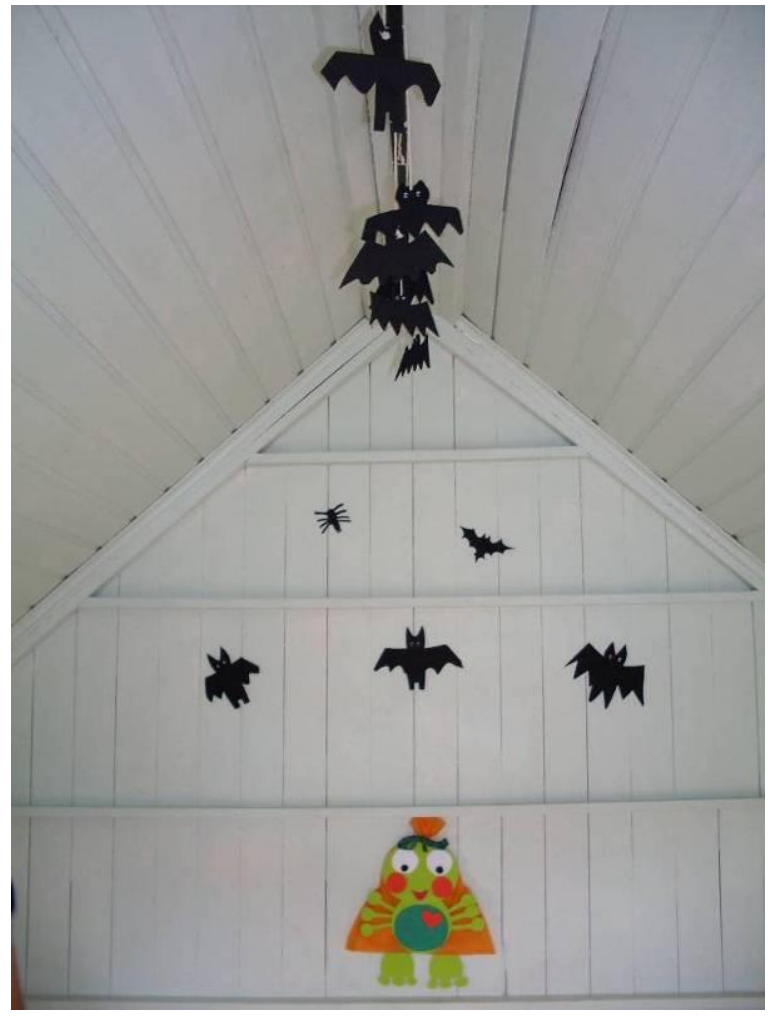

Material confeccionado: móbile de morcegos no teto e nas paredes da casinha. Enfeite de sapo na parede $29 / 09 / 08$

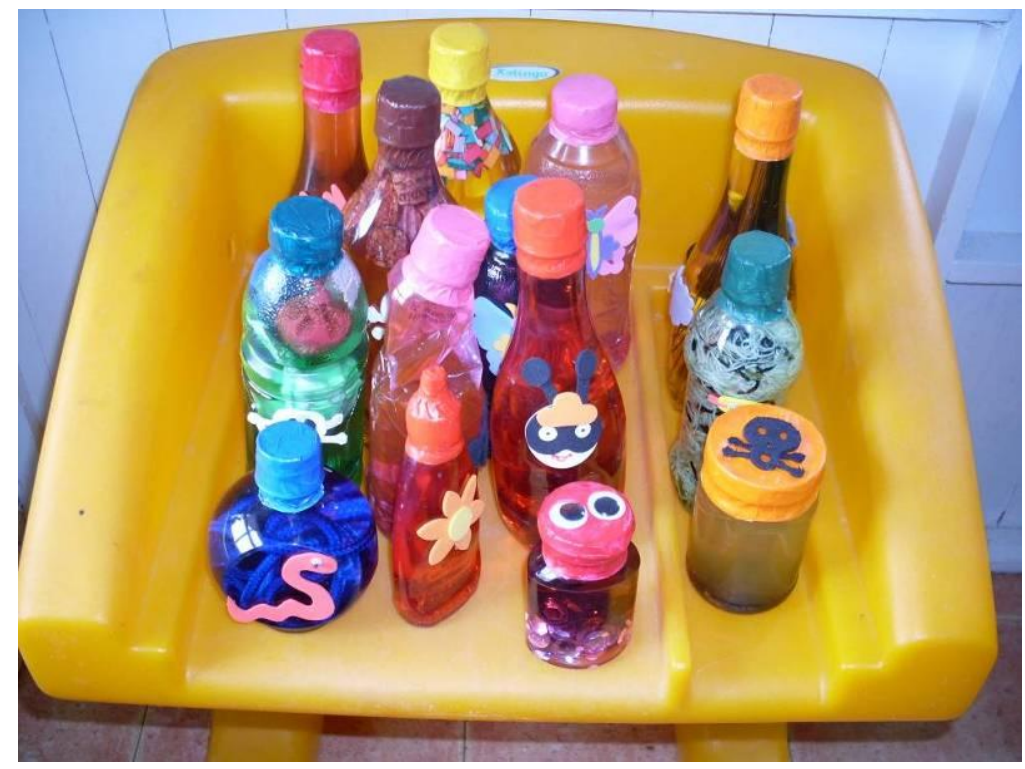

Material confeccionado: as poções mágicas decoradas.

\section{CONSIDERAÇÕES FINAIS}


Para avaliar nosso estágio, levamos em consideração os objetivos da disciplina de Estágio Supervisionado em Educação Infantil, assim como alguns critérios estabelecidos por nós mesmas em nosso Plano de Ação e em nosso Projeto de Atuação. Normalmente, somos avaliadas em tudo no curso, então, no momento de nos avaliarmos em relação ao estágio realizado, temos que visualizar por outro ângulo: passar a ver-se como avaliador e avaliado ao mesmo tempo.

No início do estágio, durante a semana de observação do grupo 3A, foi como esperávamos, pois já estávamos "preparadas" para conhecer o grupo, a professora, a instituição enfim, tudo nos parecia já fazer parte dos nossos estudos no curso de pedagogia. Não tínhamos muita certeza de como seria o comportamento das crianças referente à nossa presença, mas foi, de maneira geral, conforme havíamos imaginando. Elas nos receberam com sorrisos, curiosas, às vezes receosas e assim, aos poucos, fomos nos conhecendo, familiarizando e nos ajudando a nos inserirmos tanto no grupo quanto no cotidiano da instituição.

O período de observação foi, portanto, dentro das nossas expectativas, mas também nele descobrimos aspectos do cotidiano de uma instituição de Educação Infantil que para nós ainda eram pouco conhecidos como: saber que existe hora do lanche, modos como as crianças podem ser servidas, que tipo de alimentação, como é possível organizar e fazer a higiene, aprender a trocar fraldas, como cuidar e brincar com as crianças no parquinho, quais as propostas que elas preferem e porque, como proceder com determinada faixaetária, entre outros. Experiências, aprendizados e ensinamentos para nós, futuras pedagogas que são fundamentais. Para muitas pessoas parece simples, enquanto na verdade é "simplesmente complexo". É preciso estudo e pesquisas, dedicação e prática para trabalhar com educação infantil, é preciso aprender ou reaprender a brincar, a escutar as crianças.

O principal ensinamento dessa fase de observação foi conhecer como é o cotidiano de uma instituição de educação infantil, nos aproximar das crianças e de suas linguagens.

A segunda parte do estágio supervisionado foi completamente diferente do que imaginávamos. Devido aos fatos que mencionamos anteriormente, como o número de adultos dentro da sala, as crianças não terem uma prática específica com brincadeiras em 
espaços e períodos de entrada e saída e com a possibilidade de ampliarmos os diálogos entre os grupos, mudamos o nosso projeto de atuação.

Foi uma fase complicada, ficamos um pouco perdidas, pois estávamos acostumadas com apenas um grupo de referência, havíamos planejado atividades, tínhamos fotos, material específico para aquele grupo, idéias e um projeto. No começo, com a decisão da mudança de grupo e de projeto, ficamos um pouco inseguras, mas depois, com a pesquisa sobre o que seria melhor e mais proveitoso para nossa prática de estágio, nos sentimos mais confiantes e dispostas a continuar.

Tivemos que pensar em um novo projeto que abrangesse tudo o que gostaríamos de desenvolver, promover, experiências e aprender com as crianças. Com isso, depois de algumas reuniões com a coordenadora da instituição e com nossa orientadora de estágio, organizamos nosso planejamento considerando a seguinte temática: "as brincadeiras e modificações do espaço na educação infantil”".

Toda a mudança gera insegurança, o novo, o desconhecido, as dúvidas, as expectativas que nos fizeram seguir outro caminho e conhecer outros contornos da própria prática pedagógica com crianças pequenas. Esse contexto, nos auxiliou a perceber a complexidade da trama que constitui o cotidiano de uma instituição de educação infantil. A mudança de projeto e de grupo de atuação, nos fez ver uma outra realidade, uma realidade diferente daquela centrada num único grupo de crianças. Esse "diferente”, acabou se tornando melhor do que esperávamos, porque podemos conhecer um pouco de cada grupo, de cada faixa-etária, dialogando entre os mesmos. Sendo que, se ficássemos em um único grupo somente não teríamos essa oportunidade.

Avaliamos a questão da "construção" da casinha de histórias uma experiência muito boa, porém trabalhosa. Acreditamos que fazer um trabalho desse tipo, estando dentro de sala como professora, seria muito complicado, pois demanda tempo para pesquisa de imagens, para a construção dos materiais utilizados e para organização destes no espaço da casinha em si. Após todo trabalho pronto, em menos de dois dias, já não existia nada na casinha. Sabíamos que as crianças iriam brincar e, como conseqüência, a casinha não ficaria intacta muito menos os objetos ali colocados, mas achamos que faltou um pouco de orientação de todos nós para as crianças em relação ao cuidado com o material. Talvez assim, pudéssemos ter evitado o rápido "desaparecimento" dos "doces e morcegos", pois 
nem mesmo todas as crianças da instituição puderam ver e brincar com os objetos lúdicos ali colocados. Pode ser que a distribuição dos objetos e do cenário de "bolos e bruxarias", teve relação ao fato das crianças não terem participado do processo de construção dos objetos ali expostos, mas será que por isso devemos permitir que elas os destruam? Como intervir nestas situações? Como ajudar as crianças e nós mesmos, a brincar, a lidar com situações como estas?

Entre as crianças que brincaram na casinha e com os objetos lúdicos (brinquedos) ali colocados, observamos e destacamos a reação, as expressões e falas de felicidade e entusiasmo destas em reconhecerem elementos de histórias infantis por elas conhecidas, e ouvirem e criarem histórias dentro daquele espaço. Com aquelas que, mesmo pouco tempo tiveram para explorar ou fruir aquele cenário, aquele novo espaço e tempo organizado para o seu brincar, compartilhamos a nossa frustração ao não prolongamento do acesso à fantasia e a ludicidade que o encontro com a casinha nos parecia oferecer. Igualmente compartilhamos os belos momentos de magia e encantamento ali vividos.

Aprendemos ao longo do estágio a planejar, a ter sempre um plano "B" em mente, a pensar em todos os materiais possíveis de se trabalhar, pesquisar, ir em busca de algo diferente para as crianças e não achar que é o fim do mundo se o que planejamos, em algum momento, não saiu como esperado. Tirar proveito dos acontecimentos para saber como proceder na próxima vez, como evitar, saber também que o tempo (clima) pode ser um amigo ou um inimigo, dependendo das nossas atividades propostas, enfim, aprendermos a planejar cada detalhe por menor que pareça, visando sempre à formação global das crianças, e aqui, em particular, a expansão da sua dimensão lúdica, imaginativa.

Em relação ao brincar e a brincadeira, que foi o centro de nosso projeto de estágio, em espaços e tempos como a entrada e saída das crianças na instituição, podemos afirmar que é de extrema importância o seu desenvolvimento sistemático e intencional. Quem sabe, até mesmo um profissional que fique responsável pelas brincadeiras, a fim de construir um diálogo entre os grupos da instituição, trabalhar as múltiplas linguagens e possibilitar que a atividade lúdica seja o eixo das nossas ações com as crianças e seus familiares na entrada e saída e, é claro, em outros momentos. 
Portanto, com relação a nossa avaliação de estágio podemos concluir que é necessário encarar as mudanças não como algo ruim, mas como desafios que fazem você aprender, crescer e acreditar que é possível ser melhor. 